\title{
Freedom as a Means and a Goal in Comenius's Philosophy of Education Peter Kondrla
}

DOI: $10.32725 /$ cetv.2021.032

\begin{abstract}
:
The article examines the philosophical principles of the Comenius's educational system and compares them with the postulates of contemporary pedagogy. It analyses the goals and methods of the educational process. With regard to educational goals, attention is paid on the one hand to the development of personality and, on the other hand, to social needs and interests. Educational methods are analysed and interpreted in terms of their focus on repetition of actions or on the development of competencies leading to a creative process of authentic self-realisation. Analyses and interpretations of goals and processes are synthesised into the philosophical concept of the human person. In the philosophical explanation, attention is paid to the person and his being. These are to be developed in the process of education and achieved by this process as goals. In the context of the philosophy of education, the question arises whether the goal of education is to create an individual whose actions are a repetition of learned patterns or a person who makes decisions based on moral principles. Emphasis is placed on human freedom, which is a basic precondition for decision-making and action, and which is a necessary condition for accepting responsibility. The different ways of understanding freedom in Comenius's philosophy of education and in today's pedagogy are not only a source of criticism of pedagogy, which rejects responsibility and rational reasoning for decisions, but represent also motivation for alternative philosophical interpretation of education in the postmodern environment.
\end{abstract}

Keywords: goals and methods of education, philosophy of man, freedom, Comenius, postmetaphysical pedagogy

\section{Introduction}

The general focus of the research in our article is to find an answer to the question of whether Comenius can inspire us today. Instructed by Hegel's interpretation of history, we know that past epochs and the thinking in them should not be examined through today's lens. In other words, we should not apply the rationality we consider valid today to Comenius's thinking, because his historical and especially epistemic environment and conditions were different. Despite this warning, we will not resist temptation and will interpret Comenius's ideas through the categories of rationality of the early $21^{\text {st }}$ century. 
The reason why we dare to take this step, that is, why we interpret Comenius through our thinking, is simple and obvious. Many of today's educational institutions, from the lowest to the highest, which prepare future teachers for their profession, invoke Comenius's legacy and continuity with his teachings. Comenius is described as the founder of pedagogy. There is a comeniology that examines his contribution and significance for today. There are journals that map his contribution and update his ideas in accordance with current conditions. This continuing interest is a sufficient reason for us to be able to postulate the way of saying that Comenius is an inspiration for today's pedagogy and philosophy of education.

Our intention is to compare the goals and methods of education given by Comenius with current concepts of education, which are defined in official documents and determine the direction of the entire education system in the Slovak Republic. We assume that both goals and methods will be different. Confirmation of this assumption will be analysed in terms of the philosophy of education and we will determine what is the fundamental difference in the setting of goals and processes of education.

Defining the fundamental difference between Comenius's philosophy of education and the state concept of education will allow us not only to answer the question of whether Comenius can be an inspiration for us, but also to answer the question of how he can be an inspiration for us. We will pay special attention to freedom in the process of education, because it is a key concept in the philosophy of education and at the same time it is a cardinal concept in defining the goals and methods of education.

\section{Different Goals of Education}

The goal is a key milestone in any educational process.

The goals of education and its content are understood differently in the literature, from a strict definition of requirements concerning the rational side, through emphasising the all-round development of the individual, to precise listing of the individual components that make up the goals and content of education. If we perceive the goal and content of education through individual components, education acquires the character of a multilateral didactic category. ${ }^{1}$

We will focus on the general goal, which, in terms of the philosophy of education, pursues the importance of pedagogy for the holistic development of the individual, that is, what education brings to man as a person.

In general, the goal also means the end, reaching the place to which the path was directed. In some cases, for example in education, we assume that the goal is the ideal, the goal is unattainable, the goal is a lighthouse that leads us along the path. In other words, education is a process that does not end, and a person is in the process of permanent personality formation during his life. He constantly verifies the skills and knowledge he has acquired and, at the same time, redefines his attitude to the world, his understanding and meaning of the world. Education, like philosophy, is a never-ending stream of raising and asking new questions. ${ }^{2}$ Education is closely and directly connected with a person's self-realisation. As long as a person thinks and implements his decisions, he is still in the process of education, because he still comes to know,

Erich PETLÁK, V̌̌eobecná didaktika, Bratislava: Iris, 1997, pp. 35-36.

2 Cf. Miroslav PETŘÍČEK, Myšlení obrazem. Průvodce současným filosofickým myšlenim pro středně pokročilé, Praha: Hermann \& synové, 2009, pp. 45-46. 
understands, and adjusts his attitude to and understanding of the world.

The goals of education integrate two basic elements - the interest of society and the interest of the individual who is being brought up. It is therefore either the needs of the society that shapes and educates man according to its requirements and ideas, or it is the needs of the individual, where education takes into account the needs and dispositions of the individual as much as possible. Ideally, it is possible to integrate both to the same or adequate extent in the goal of education. This means to develop an individual's abilities and personality in a way that benefits others, society as a whole. ${ }^{3}$ In the goals of education, Comenius sees man above all. He considers the school to be a workshop of humanity. Its aim is that 'people will be educated in being true people and true Christians, and the school must enable them to acquire a wise mind, the ability to work, and the refinement of morals. ${ }^{4}$ Education of the individual is also reflected in the broader social context, which we can call, using Comenius's term, the general reform. ${ }^{5}$ The general reform can be interpreted as a complex reconstruction of society, the effect of which should be general harmony - panharmony. ${ }^{6}$ The panharmonic conceptually overlaps with today's globalised or global society, so Comenius's ideas can be considered extremely topical in this sense as well. Nations and nation-states represent specific historical values, but these values are based on defining oneself against another, against the otherness of others, defining oneself through differences from others. Panharmony is, expressed in terminology given by Nicholas of Cusa, a fusion of these national opposites and specifics into the unity of the universal values that are bound to the nature of man. Comenius's goal, then, is a universal order, a kingdom of God here on earth that can be achieved through education. Man, in essence, is not evil. This starting point is given in the theological notion of sin and the possibilities of human correction through good deeds. A brief philosophical outline of Comenius pedagogy could be expressed in the assumption that man is good and through education we help him overcome obstacles on the path to perfection. His perfection contributes to the improvement of the whole human society and its directing to the Kingdom of Heaven, which is the culmination of the history of an individual and society as well. The necessity of education is justified by the fact that one does not have sufficient means in himself to develop into perfection. The interruption of the vital relationship with God causes one not to pursue the goal set by God. Therefore, a permanent remedy in the form of education is necessary. ${ }^{7}$

Together with Patočka, we can state that if we consider Comenius's didactic approaches to be outdated and unusable in our conditions, we can still be inspired by the phenomenon of humanity. This is as important to us as it was to Comenius, and we consider it a means of achieving the general reform. ${ }^{8}$ One of the basic elements of the phenomenon of humanity is freedom. According to Comenius, the remedy does not lie in the restriction or even in taking away one's freedom, but in its development. The educated disciple is not a prisoner who must obey. He is a free being who develops his essence. Developing freedom does not mean gaining space for arbitrariness. Man's goal is not primarily to fulfill his will. He should fulfill the will of God. Education helps to

\footnotetext{
Cf. Jaroslav OBERUČ et al. Teória výchovy v procese výchovy a vzdelávania, Dubnica nad Váhom: DTI, 2019, pp. 66-67.

Jan Amos KOMENSKÝ, Zákony školy dobrě uspořádané, in Vybrané spisy Jana Amose Komenského, Praha: SPN, 1960, p. 270.

Jan Amos KOMENSKÝ, Všenáprava, Brno: Soliton, 2008; cf. Jiřina POPELOVÁ, Jana Amose Komenského cesta $k$ všenápravě, Praha: Státní pedagogické nakladatelství, 1958; Dagmar ČAPKOVÁ, Myslitelsko vychovatelský odkaz J. A. Komenského, Praha: Academia, 1987.

6 Jan Amos KOMENSKÝ, Obecná porada o nápravě věcílidských, Praha: Svoboda, 1992; Jan PATOČKA, Bacon Verulamský a Komenského Didaktika, Komeniologické studie: soubor textů o J. A. Komenském. 1. díl, Texty publikované v letech 1941-1958, SCHIFFEROVÁ, V. eds., Praha: OIKOYMENH, 1997, pp. 265-266; cf. also Jan KUMPERA, Jan Amos Komenský, poutník na rozhraní věkư, Praha: Svoboda, 1992.

7 Význam celoživotnej výchovy a vzdelávania predstavuje predovšetkým diele Pampedia. Jan Amos KOMENSKÝ, Pampedia, Bratislava: Obzor, 1992.

8 Cf. Jan PATOČKA, Komeniologické studie II. Sebrané spisy, sv. 10, Praha: OIKOYMENH, 1998, pp. 359.
} 
restore the broken bond, the essential attachment of man to God. Man is also hindered in this renewal by his self-loyalty, which takes him away from God to earthly good. Only by breaking through this shell of self-loyalty can the human soul find itself in an area of openness to God and overcome its focus on the inner-secular being. ${ }^{9}$

A well-organised society is also a social aspect, which is incorporated into the goal of Comenius's education. A well-organised society is a very broad concept. We can imagine it as a society in which people do not deceive and steal, because they know that it is bad and that it does not benefit anyone in the end. It is a society in which the authorities respect their subordinates, because they are human beings with their own dignity. It is a society where one can and wants to take care of oneself and at the same time cooperate with others for the common good. The basis for correction is an active person. 'In Comenius's pansophical and reform writings, in contrast to the comforting writings, we can trace an obvious emphasis on the aspect of human understanding that is related to production and activity. However, this has its meaningful fulfillment only in the supra-individual context of the general reform and universal unity.' ${ }^{\prime}$

Achieving the reform is not possible through restrictions on freedom and the direct management of individuals. Such management of society produces social tension, dissatisfaction. Comenius's path towards the reform has its foundations in upbringing and education, that is, in understanding what one should do, and subsequent acceptance by the will. The final effect of education is a person who knows what is good and at the same time wants to do this known good. The basic premise of the general reform is the belief that the world can be fixed by education. This means that we will teach man not only to cultivate the land more efficiently, but also to teach him how to understand the environment, how to understand the people around him. Man understands himself as part of the system. He does not interpret himself as a ruler, but as a steward. ${ }^{11}$ Education is the process which gradually brings knowledge into one's mind. This knowledge changes the way of seeing and understanding the world. It is not about passive knowledge needed to produce goods. It includes active knowledge, vision, and understanding of the world. Upbringing and education internally construct a person's attitude to the world, shape his worldview, and thus determine the ways of self-realisation, that is, how he decides and what he will do. The goal of upbringing and education is a virtuous person - a person who knows good and acts well. This Socratic ideal is also the key to the correction of our society.

Just because man is good in his nature does not mean that he does good automatically. The premise of automatic doing of good would deny the possibility of freedom and free choice that is at the heart of the human person. The essence of man is good. In order to realise this good on the outside in the form of good behavior, it requires education. The correction of man does not lie in the transformation of his essence, but it is based on the fact that by education one learns to know good in oneself, one learns to distinguish good from evil, one learns to do good. He cannot be left to his own destiny, to a kind of natural process of self-education and self-upbringing. Although man is good in nature, he cannot develop this essence on his own. According to Comenius, man is created according to the image of God. This fact determines man's responsibility for the world, nature, and other people, but also for himself towards God. Due to the fact that he is created according to the image of God, there is a reflection of perfection in him. However, this bud needs

9 Eva DĚDĚČKOVÁ, Komenský a Fink - svet sub specie educationis, Paideia 3, XIV, 2017, p. 2.

10 Vladinír LEŠKO et al., Patočka, fenomenológia, dejiny filozofie, Košice: UPJŠ, 2013, p. 76. Cf. also Vladimír URBÁNEK, Lenka ŘEZNÍKOVÁ, Ex definitione (Pansofické pojmy J. A. Komenského a jejich dobové kontexty). Praha: Filosofia, 2018.

11 Jan Amos KOMENSKÝ, Velká didaktika, Didactica magna, Bratislava: SPN 1991. Cf. tiež Jan PATOČKA, Bacon Verulamský ..., pp. $151-153$. 
to be developed and cared for through education. Education is the correction of a broken relationship with God and the guidance to perfection as well.

From the point of view of the current goals of upbringing and education, Comenius's general reform seems to be a utopian ideal. Our ideas and goals of current education and upbringing are defined in the priorities of the government, which determines the direction of the school system. The state and society manage the area of education in the same way as the area of investments. Although they declare that education should serve the development of pupils' personality, they also show the need to connect schools with the labour market. In other words, the labour market decides in which direction education and upbringing will develop. The government's programme statement even says that universities should be able to respond to changes in the labour market in a sufficient and flexible manner. ${ }^{12}$ This means that the wisdom of universities should be subordinated to the needs of companies with the need of manpower. The aim of education and upbringing is to prepare students for better employment. In other words, effective education is one that makes it as easy as possible for a student to find a job that is well paid.

Although it is explicitly stated in the individual lessons of specific pedagogical and didactic textbooks that in the process of education it is necessary to comprehensively develop a pupil's personality in all directions, the practice is different. Project challenges aimed at education are focused on the labour market, and the state does not support the development of personal competencies. Mainly, it prefers the development of work skills that will allow students to find employment. The state, while financing schools, sees them as an investment which should pay off (not in the form of a well-organised society, but in the form of higher gross domestic product). The state thus perceives its future citizens as potential producers of tax payments and constantly emphasises this fact. The importance of the humanities is questioned - they have been underestimated for a long time, and education in economically-interesting sectors is supported. The reform of public affairs is therefore a matter of public finances. Man is primarily perceived as the one who generates financial inputs and ensures the running of the economy.

In addition to labour market orientation, pedagogy also confronts another problem. Petlák describes the problem as follows: 'Unfortunately, despite the excellent elaboration of individual educational areas, real educational practice accepts only a few, even very few of them. ${ }^{13}$ In practice, this also means that there is a discrepancy between declared and real goals and ambitions within the pedagogical process. Therefore, we will continue to treat this statement as a fact.

In our school system, there are defined goals that primarily pursue the interest of society. We know what we expect from a person, and we lead him to it. In Comenius's case, the goal is to create an existential basis, a kind of basic essential equipment, on which one can build one's subsequent existence. The current school system, at least the Slovak one, prepares students for specific situations, and it has ready-made solutions that will be followed. Our education system prepares for problems that may arise within the system only. These solutions are often unusable in another system or culture. Comenius's pedagogy prepares a person to be able to navigate himself in any new situation. The goals of his pedagogy are universal, we would say global.

Patočka sees it similarly:

Every effort to help a person which ignores the fact that he has to help himself, that he can and wants to help himself, that he needs to be given a good opportunity to do so, that people must be guided, help each other, provide themselves with everything necessary to freely become

12 C) Programové vyhlásenie vlády SR, 2020 (online), available at: https://www.mpsr.sk/download.php?fID=18769, cited 26 ${ }^{\text {th }}$ July 2021 , p. 71.

13 Erich PETLÁK, Inovácie v edukačnom procese, Dubnica nad Váhom: DTI, 2012, p. 7. 
participants in humanity - every effort of this kind must fail. It can provide man with every skills he or she needs in an economical and reliable way. It can help create a skilled person, an expert, or a virtuoso, but it cannot bring a person to oneself or raise a person. It cannot see the core of this act or a problem if there is one. ${ }^{14}$

The difference between the goals of Comenius's education and the goals of our educational system, as Patočka's quote suggests, lie in the very basis of understanding the nature of man and his being. The goals of education in our educational system are not set to bring man to introspection. To understand oneself is a necessary condition for understanding one's place in human society and in the cosmos, as Scheler would put it.

\section{Different Ways of Education}

Ways of education are the means through which we achieve set goals. It is clear that the choice of means also depends on the objectives and their definition. If the goal of education is to teach a child to repeat an activity without meaning, then it will not be necessary to develop creativity in him. Rather, it will be efficient to develop subconscious reactions to a certain stimulus. The choice of means of education depends, similarly to the goals, on the basic setting of the philosophy of education, specifically on how the person - the student - is defined, what skills he has, what his purpose is, etc. All of this determines the way in which the education will take place.

Comenius defines the basic way of education simply as a comprehensive education for all, that is, as an education which is for all, universal, and versatile. In his General Consultation on the Improvement of Human Affairs, he expands this simple requirement into a broader content:

One should understand the incorporation of things, thoughts, and speeches. One should understand the goals, means, and implementation methods of all actions (one's own and someone else's). One should be able to distinguish the essential from the accidental, the indifferent from the harmful in all actions (as well as in thoughts and deeds), among things which cause distraction or confusion. One should be able to recognise the twists and turns of his thoughts, words, and deeds (someone else's and one's own), and to learn to return to the journey anytime, anywhere. ${ }^{15}$

This demand of Comenius reflects the basic idea of Christian philosophy about man and his actions. Man is created as rational, that is, one who can know good and distinguish it from evil using his reason. The distinction between good and evil does not happen intuitively; it comes consciously, rationally. The ability to distinguish between good and evil develops in a person by educating his conscience.

There is a presumption that a person is reasonable and that his reasonableness can be developed and practised through education. Developing rational judgment enables one to do good. Knowledge alone is not enough to do good. It is also necessary to influence willed aspects of action, so that doing good becomes easy, i.e., virtues need to be developed. Through the process of developing, an individual a person is formed. He is then a full part of society. If someone has harmonic thinking and actions, then he applies it in his external actions. A society of educated individuals does not need government because it is governed by its own reason and does not need to be managed. A virtuous person is not lazy; he does not wait until someone challenges him or forces him to do good. On the contrary, he does good on his own, because he understands doing

14 Jan PATOČKA, Komeniologické studie II..., p. 355.

15 Cf. Jan Amos KOMENSKÝ, Vševýchova - Pampaedia, Bratislava: Obzor, 1992, pp. 22-25. 
good as part of the self-realisation of his own existence.

Achieving the common good is spontaneous and does not have to be controlled. Jan Patočka reminds us that 'The reform of human affairs, specifically those which come natural to man, uses education as its norm, criterion, and goal. Reform action occurs and happens when every individual and all societies become the bearers of the process of education, namely the bearers of the path of man to humanity. ${ }^{\prime 6}$ The general reform that we have identified as the goal of education is achievable by transforming the educational effect into practice, so that wise good-doing becomes practice. It follows from the above that the method or methods of education that Comenius deals with are of a complex nature. Know, understand, want, act. This could easily sum up his understanding of the path that the pupil should follow. Knowledge is a necessary condition for understanding the world, for understanding the principles and determination. One could say that knowledge is important for understanding the essence of why the world is the world and man is man. These ideological starting points are a condition for one to be able to find one's place in the world and to be able to find one's place among people.

Compared to Comenius's conception of educational methods, current pedagogy is richer, but, at the same time, it is more limited in content. As for the methods of education, we will not pay specific attention to the individual procedures. We will focus on one common denominator - socialisation. Socialisation implicitly appears in many methods of upbringing and education. However, specifically, it appears in educational subjects. In the theory of education, the connection between the educational process and socialisation is defined as follows: 'By education in the narrower sense, we mean the gradual formation, consolidation, and development of an individual's attitudes to reality. Gaining experience creates a habit of behaving and managing one's needs, interests, and activities in accordance with societal norms and rules.' ${ }^{17}$ The goal of education is to make the student want what society wants from him. Ultimately, we could say that a socialised student is a student whose needs and value orientations are aligned with the needs of society. This is certainly not the development of an authentic personality who decides freely and takes responsibility for his decisions and actions.

In educational subjects, the tools of group work are used, which should lead students to cooperation, to the understanding of importance of cooperation, to the acceptance of the other and his opinions, but also to the expression of their opinions. These social skills or competences could be considered virtues at first sight. In this educational model, there is a contradiction between theory and practice. Theoretical education leads to the acceptance of the other, but the practice is different. The educational reality is not complex, it does not have the nature of 'pan or all-wise'. It seems to be at two different levels. One level talks about what it should be and the other about what it really is. On the one hand, there is empathy and social cooperation, and on the other, there is the struggle, competition, and understanding of the other as an enemy. This contradictory effect of the educational process is ultimately at odds with the rationality and principle we have spoken of in Comenius. Education cannot be based on rational principles, and therefore it is based on 'it should be this way' or 'it is usually done this way'. Modern education aims at social uniformity and at the same time is unable to answer the question 'why?'.

Current pedagogy works with the concept of socialisation, seeing it as a tool that is used not only in the education of children, but also in working with maladapted people, with people who have been serving sentences for a long time, or with people with behavioral disorders. The plethora of

16 Jan PATOČKA, Komeniologické studie II..., 1998.

17 Jaroslav OBERUČ et al., Teória výchovy ..., p. 63. 
people to whom socialisation is applied is very wide. Ultimately, we can say that socialisation is also used in the management of the whole society within the state, not only during the process of education or re-education. Every law passed has its own sanctions that force a person to comply with the applicable standards, and non-compliance with the standard is punishable. In the process of education, socialisation is understood as the integration of a child or adult into society. It is the way through which we make pupils respect social norms. We socialise them, and they become a part of society. ${ }^{18}$ We make him the same, similar to others. Similarities with others may or may not be an issue. If similarity is based on uniformity, then socialisation is a process of denying the authentic existence of an individual. If socialisation leads to similarity in a sense of a similar path on which people strive to do good, then it is an education that develops a personality and his personal identity. The opposite of successful socialisation is the state of anomy, in a sense which is stated by sociologists. It is a state where social norms do not apply and individuals are disoriented. Individual social groups create their own normative systems which should suit the specifics of their value orientations. Sociologists understand this process negatively. At the same time, it is a process of expressing one's own identity that points to dissatisfaction with cultural totalitarianism. In an effort to avert the state of anomy, teachers and educators use fear as a means of education. Fear of bad evaluation, fear of exclusion from society, fear of public opinion, fear of anger of others, fear of dissatisfaction of others with one's behavior, etc. ${ }^{19}$

It follows from the above that we must use different procedures to achieve different goals. The first procedure we have already mentioned is punishment or sanction. Inadaptable behavior that goes beyond the norm is sanctioned or punished. However, sanction and fear are used not only in the case of legal sanctions, but also in the school education system. Assessment in the form of a mark is officially considered feedback to the student. Marks should show a student how well he has mastered the subject matter. However, teachers also use these marks as a form of punishment in case of non-fulfillment of obligations, and parents punish bad marks using various prohibitions. Trips and material rewards are conditioned upon a 'good report card'. In connection with the distribution of report cards, problematic mental states in children, which are associated with fear and stress, are documented. Officially, no one agrees on the fact that education and socialisation are intertwined with fear, but the reality is different. The product of such socialisation is a person who does not need freedom because he repeats the behavior to which he was forced or motivated (advertising, promised reward, punishment, etc.). This form of socialisation is also used in animal training. In this context, and in connection with Maritain, Svobodová points out that human education is an art and not animal training. ${ }^{20}$

The second way is accompanying on the path of understanding. The aim of this accompanying is to make the educated subject aware of the fact that a certain type of behavior is good for him and for society, and another type of behavior harms either him, other people, or both parties at the same time. Comenius's methods in education lead to practicality, or competencies (in today's vocabulary). Whether we take into account his principle of illustration, which was an essential part of didactic and pansophical study, or the interconnection of the senses, it is always a matter of practical knowledge. Education should be appropriate to the student's abilities and should be linked to practice. Comeni-

18 Cf. Hedviga TKÁČOVÁ, Martina PAVLÍKOVÁ, Zita JENISOVÁ, Patrik MATURKANIČ and Roman KRÁLIK, Social media and students' wellbeing: An empirical analysis during the covid-19 pandemic. Sustainability (Switzerland), 13 (18), 10442.

19 Cf. Andrea LESKOVÁ and Michal VALČO, Identity of adolescents and its dimensions in the relation to Mass media: Philosophicalethical reflections, Communications - Scientific Letters of the University of Zilina, 2A/2018, pp. 16-21.

20 Zuzana SVOBODOVÁ, Natural law and integral humanism by J. Maritain: Teaching challenges, Caritas et Veritas 2/2018, p. 21. 
us literally recommends teaching nothing which cannot be used immediately. ${ }^{21}$ Likewise, his other principles, such as ease and reasonableness, student activity, consistency, but also the inculcation of piety, can be considered principles that lead students to an internally interconnected complex of life skills that lead man to knowledge and thus to God and good.

This method of education is currently referred to as competency-based education. ${ }^{22}$ The problem with this concept of accompaniment is, in our view, that it does not happen on a single platform and does not pursue a single common goal. In addition to the different approaches of teachers, there is mainly family education, which can stand in opposition to institutional education. It is meant in both positive and negative ways. A student led to an authentic attitude towards the world, himself, and others can have the opposite experience in the family. A child led by his family to autonomy and responsibility may have the opposite experience in institutional care and may be required to have attitudes that he does not understand. Despite these obstacles, we can state that competency-based education resembles the Comenius educational method, and we assume that both will be based on a similar principle of the philosophy of education. In both cases, it is an accompaniment on the path to understanding or rather permanent discovery of meanings and understanding of the world in its context. It is an understanding of the world as a whole. In such a world, things are interrelated and man is part of that whole. One understands and the same time knows what to do, how to act, and how to make decisions. He distinguishes between good and evil, and he also applies this distinction in his actions.

Comenius's pedagogical model and today's competency-based education have much in common. It is an education that aims to gain personal traits that make a person a moral personality. The necessary trait is freedom, without which one could not even decide whether or not he wants to be free. Freedom is the effect of primary choice, optio fundamentalis, which affects every further action. It is a big problem if a person is denied freedom, if he cannot be free, if education is training in repetitive activities. But the problem is also that one does not want to be free. This is the problem of our time. We deny freedom so that we do not have to take responsibility. The key decisions in life are in the hands of politicians, leaders, scientists, fortune tellers, and other external actors. These decide about the fate of man and he is only carried on the waves of what is necessary. Behaviour is attributed to genes, environment, education, but not to man himself. Therefore, he is not responsible. He prefers repetition to an authentic decision that involves risk and responsibility.

We stated at the beginning that we cannot interpret past epochs using our rationality. It turned out that Comenius and our intentions concerning education are similar at certain aspects and differ in others. The similarity entitles us to look for an interpretation which allows us to find inspiration in Comenius even today, or allow us to show common and different principles implemented in pedagogical practice.

\section{Philosophical Foundations of Education}

In our research, we want to follow the basics of education, that is, the foundations on which Comenius's pedagogical system is built, and compare it with our system. We will look for these foundations in the philosophy of education. It became clear that it is important to understand the basic purpose of man. It is the philosophy of education that can answer the questions like who

21 Cf. Jan Amos KOMENSKÝ, Předehra pansofie. Objasnění pansofických pokusů, Praha: Academia, 2010.

22 Cf. Rastislav NEMEC and Andrea BLAŠČÍKOVÁ, Two perspectives on the issue of prudence (prudentia): Thomas Aquinas and William of Ockham, In: Constantine's Letters, 14/2 (2021), pp. 51-60. 
a person is, what makes a person human, and what the purpose of education is in terms of the focus of the human person.

The philosophical concept on which Comenius built his pedagogical system reflects the possibilities of his time and, in a sense, transcends them. The authors who interpret Comenius's philosophical thinking emphasise the question of methodology and the inspiration given by Bacon or Nicholas of Cusa. ${ }^{23}$ The key concept that appears in Comenius's thinking is, in our view, freedom. It is contextually linked to the concept of the person of man. The problem of freedom creates a basic starting point for understanding to the questions like who a person is, who a student is, and what we expect from education (including the procedures we will use for this purpose). Although freedom is not always explicitly treated as a problem, whenever there is talk of knowledge and action in the process of education, there must also be freedom. The humanistic interpretation of man and freedom is based on an unquestionable foundation in which reason and freedom are essentially interconnected in the essence of man.

His [Comenius's] problem was not, as in Bacon and Descartes, the realm of man, but it was man himself. And the solution to this problem was, like in case of classical thinkers living two thousand years ago, education. This education, in contrast with the education of the chosen in Plato and Aristotle, focuses on man in general (on each man separately and all together). It does not prepare one for his own life only. Education is seen as the main component and backbone of life itself, as what makes life the human life. (...) Humanity is an opportunity that needs to be realized, to approach it as a mission. It is possible to miss it, or to make it wrong. Indeed, most people miss it. In the Labyrinth of the World, Comenius described this fact of lost, false humanity. ${ }^{24}$

Comenius's scheme of education is created within the philosophy of that time and its intentions. We could say that the ideological background of the $17^{\text {th }}$ century was very diverse and even contradictory. Comenius did not allow himself to be drawn into Cartesian dualism, which offers two options and one choice. He does not see man as a thinker, as pure consciousness, but he sees man as an integral connection of body and soul in which self-realisation takes place. ${ }^{25} \mathrm{~A}$ synchronised understanding of the relationship between body and soul is important for Comenius's education. This ensures that the process of education leads to the active use of the skills developed by education. One should not engage in meditation like Descartes would wish for. One should engage in active correction of the world, making the world a better place, and this is possible only through active action.

Comenius is also confronted with religious or theological exclusivism, in which only one religion is true and it is necessary to fight wars victoriously to achieve the truth. The resolution of conflicts was not understood in a dialectical way (not even in their interpretation as opposites which ultimately form a complex of absolute unity). On the contrary, everything else must be defeated and rebuilt into the same. The other that is perceived as evil must be defeated. For Comenius, the path to truth is at the same time the path to general reform. This path does not lead through the defeat of untruth, but through the understanding of contradictions, through the understanding of the unity that is formed by opposites. In addition, Nicholas of Cusa points out that the intellect is not the truth, it will never understand the truth so precisely that it could not be understood more accurately (and this process can run indefinitely).26 The human intellect does not have the definitive

23 Jan PATOČKA, Komeniologické studie I. Sebrané spisy, sv. 9, Praha: OIKOYMENH, 1997, pp. 152-155.

24 Jan PATOČKA, Komeniologické studie II..., p. 354.

25 John R. SEARL, Mysel', jazyk, spoločnost', Bratislava: Kalligram, 2007, p. 40.

26 Mikuláš KUZÁNSKY, O učenej nevedomosti, Bratislava: Pravda, 1979, p. 37. 
truth which one could use to judge untruth. On the contrary, the intellect is always on the way and everything it confronts is part of the path of cognition. The holistic view, the world as a whole, the whole of humanity, and the wholeness of the person is the philosophical key to understanding the path of pedagogy. Comenius's pedagogy does not aim to break, humiliate, defeat in battle or scholastic dispute, polarise or condemn. His aim is to understand in the context of the whole and to contribute to the development of oneself and society as a whole through one's own activity.

In many places, Palouš draws attention to the connection between Comenius' metaphysical views and his pedagogical views, which is often pushed aside in the positivist interpretations of Comenius' pedagogy. Comenius' successes in the pedagogical (didactic) field tend to be explained the way as we usually build science today - as a set of rules and lessons derived from the experience that Comenius experimentally gained and then verified during his rich pedagogical practice. According to Palouš, however, it is different. Comenius' pedagogy is not induced from the 'lower'. On the contrary, it is derived from his insight into the nature of the world and the role of man in it. Comenius' pedagogy is thus an inevitable consequence of his natural philosophy - and not the other way around! ${ }^{27}$

Comenius's philosophical foundations reflect Comenius's experience. The philosophical reflection of the world is not adapted to the innate ideas that should determine how we will see the world. On the contrary, the worldview, its image, and contexts determine the educational goals as well as the methods. Freedom is always implicit in the formulation of pedagogical practices. As we have already said, freedom is an important part of Comenius's education. It is a necessary precondition for developing a person through education (not for constructing man according to one's ideas, but to assure that education is a process of developing an authentic person on the basis of his nature, on the basis of what is essentially human). In today's pedagogy, freedom and respect for it is a basic and unquestionable starting point for the pedagogical process. Today, we perceive education as help in developing students' personality. The basic premise is that we help a person to develop himself. We do not want to develop our own ideas about him and his future development. In a sense, a person is a secret that is veiled to us, and we help to uncover him. We do not determine what happens. We help him in his own decision and self-creation.

Comenius's acceptance of human freedom as the primary starting point in education was not present from the beginning. Given the medieval conception of absolute truth, Comenius also proceeded from the idea that truth is something complete, something which we pass on in the process of education as a finished set of valid statements and knowledge. Truth was not understood as the object of search and revelation, but as content that one passively accepts into one's intellect. The absolute nature of truth implies its immutability. One can only decide whether to accept the truth or not. When he accepts it, he will be saved; when he rejects it, he will be damned. This absolute concept does not make it possible to accept part of the truth (and reject part of it). It is also unacceptable for man to reveal the truth himself, to gradually work towards gaining knowledge. This is dangerous because the seeker can become lost, make a mistake, and a mistake is not allowed. In this sense, freedom of education is a problem, especially when it comes to religious education. In the process of education, one can develop one's own knowledge. This then can contradict what is in the textbooks, what is to be taught.

In this sense, Comenius transcends the boundary that separates education as shaping from

27 Dalibor VIK, Konzultace s Komenským na prahu světověku. Nástin hlavních rysů Paloušovy komeniologie (II.), Paideia: Philosophical e-journal of Charles University 1/2020, p. 4. 
education as accompaniment. Education as a transfer of information does not need freedom. It defines what the student has to do. This is then required of him. It is not the catechism-like offering of ready-made answers. It is the search for answers that make sense and bring uderstanding to a concrete person. Comenius understands rational knowledge, like Bacon, as a tool to control nature, but not to control man. As Patočka points out, Comenius's man should understand the cosmic plan of which he is a part, and he should actively cooperate in this plan. He cooperates with God to fulfill God's plan, and he needs reason to do so. Thanks to this, he also gains space for free self-realisation. ${ }^{28}$

However, current pedagogy is moving in the opposite direction. At the beginning, it declares freedom as the basic starting point for the development of personality, but it is no longer able to actively cooperate with freedom in individual methods. If we wanted to characterise the starting point of contemporary pedagogy in terms of the philosophy of education, we could say that it is a pedagogy that develops in philosophy beyond metaphysics. Generally and popularly, we could express it in terms of postmodern philosophy. According to Petříček, this period begins with Nietzsche and his announcement of the death of God. It is the death of a man-made god, so he is a god who can die. The god represents metaphysics and the system. Postmodern philosophy, as described by Lyotard, is characterised by the destruction of the system, the emphasis on marginality, the rejection of repetition, the emphasis on chance, and also by a certain dose of scepticism and reticence in relation to the possibilities of cognition. In such conditions, and this is crucial for pedagogy, man turns out to be a great unknown, man's knowledge is limited, man creates his own image of the world. This world makes sense to him, but this world is alien to other people. One lives in one's own sense and in one's own world of meanings. One cannot tell others about this, and if so, it is an approximate picture only. Such a presentation of one's personal experience of the world is created through metaphor or art.

From the point of view of the philosophy of education, in such an environment, we cannot define the goal of education. There is no authority to determine what is good for all. There is no plan according to which the universe works (not in the sense which was applied by Comenius when working with it). There is only one individual who decides for himself what is good for him; he decides for himself how he should be brought up and what he should be led to. The general rules for pedagogy are then theoretical; they do not give the possibility of a concrete expression of the values to which education is directed. The overexposed emphasis on freedom is not balanced by the emphasis on responsibility or rational decision-making. Metaphysical thinking has rejected the system, rejected repetition, and prioritises chance. The pedagogical ambitions of the educator are thus frustrated, because even goal setting cannot be achieved through logical steps and procedures. We must take into account the presence of chance and the fact that a number of unexpected variables enter the educational process. These divert our path to an unforeseen goal. One goes through a series of random events in one's life. It is often difficult to understand them or to deal with them.

The centre of contemporary pedagogy is the concept of freedom. However, it is a different understanding of freedom compared to Comenius. For him, freedom is the way which helps man fulfill his own existence. He understands his existence as a path to a goal, which is realised by doing good. Moral principles underlie every decision, and without moral principles it is not possible to proceed to the goal. All this is possible only if the rules work, that is, if it is based on valid corre-

28 Jan PATOČKA, Základní filosofické myšlenky Jana Amose Komenského v souvislosti se základy jeho soustavného vychovatelství, Komeniologické studie I..., pp. 258-260. 
lations of metaphysics. In such a system, a person is able to formulate the goal of his existence, express his path, possible future achievements, values, respected elements. At the same time, he can justify why he thinks in this way. The post-metaphysical man, unlike the metaphysical man, does not know where he is going. He has nowhere to find the answer to this question. He is a man who stumbles on a stormy sea of chance, solves problems as they come, and does not try to follow the horizon to which he would like and should move towards.

\section{Conclusion}

At the beginning of our article, we asked ourselves whether Comenius can inspire today's pedagogy and in what aspect. From the point of view of pedagogy, we found a lot of inspiration. We focused on one basic moment of inspiration, which is freedom. Freedom forms the basis of the philosophy of education for both Comenius and contemporary pedagogy. The interpretation of the consequences is different. The basic difference is that Comenius's philosophy of education is based on the assumption of the existence of a valid order. It is a cosmic order that is established by the Creator, and it follows clear rules that govern it. The current philosophy of education, unless it is built on religious foundations, is based on the assumption that the order is unknowable or non-existent. Either we cannot explain why things are happening, or we give up the possibility of an explanation because there is no reason for such a thing.

Comenius assumes that metaphysics reveals to us the rules of causality. These clearly tell us that doing evil brings disorder and doing good brings order and harmony. The metaphysical system shows us that the world of order brings man not only a happy life, but also prosperity for all. In order to manage all this, Comenius offers an education through which a person learns the individual steps leading to cooperation on a general order and to a general reform. Palouš interprets this as follows:

Considering Pampaedia, if education today is conceived as a means of acquiring the appropriate personality equipment for life in nature and in society, it is a matter of making a person what one should be. In this sense, man is never an object of manipulation, a substance which should be formed and informed, a mechanism which should be programmed. It is his destiny, the whole to which his life belongs. In responding to the challenge of general meaning, he goes beyond human closedness into partial matters: and he needs to truly live that responsibility. ${ }^{29}$

The philosophy of man without metaphysical anchoring emphasises one-sided freedom. One can choose any path without taking the responsibility and dealing with the consequences of one's decision. Post-metaphysical freedom makes man a victim in the existentialist sense. One chooses something, but he does not know what the consequences of his choice will be. Sartre saw man's fate in the fact that he chooses and must take responsibility, even though he does not know the consequences. This is where we can find Comenius's greatest source of inspiration.

It is not true that we do not know the consequences. We have already described them above, and they are very simple. Doing good brings both individual and social benefit, doing evil leads to the opposite. The method of trial and error does not apply in the area of moral decision. Just as the karmic system does not apply, that is, if someone does evil, it will go back to him immediately. Comenius's responsibility in education is based on the assumption of the existence of a cosmic system made by the Creator. Solitary decisions of an individual do not reverse the whole system, 
but slowly disrupt it. One discarded plastic container will not disrupt the ecosystem, but our longterm irresponsible behaviour will. Although man looks like an insignificant creature on a global scale, he is very important in terms of individual existence.

A new understanding of freedom without metaphysics also leads to the fact that human society ceases to be a being and remains only an existence..$^{30}$ This means that one concentrates on one's own freedom without caring about another person. Other people become the means. Patočka recalls that 'Man who is not seen as a means or a thing (a thing is always a means) must be captured in his humanity. Certain aspects like one's nature, the basis of one's dominion, one's limits and conditions must be set. An approach must be created so that man can always truly become that master. ${ }^{31}$

If we are to determine the principle to which we should and could return in pedagogy, then it is wholeness. It is the wholeness of the universe, the wholeness of human society, and the wholeness of the human person. Educating a person means helping him to become a part of these units. This is done through understanding his place and position in the world and in human society and through awareness of his activity (what and why), including taking responsibility for his decisions and actions.

\section{Contact}

Assoc. Prof. PaedDr. PhDr. Peter Kondrla, PhD.

Constantine the Philosopher University in Nitra

Faculty of Arts

Department of Religious Studies

Hodžova 1, 94974 Nitra

pkondrla@ukf.sk 